\title{
THE SHOPKEEPER'S PRIVILEGE AND CANADIAN TORT LAW
}

\author{
MitChell MCINNES $^{*}$ AND AdAM SIMPSON ${ }^{* *}$
}

\begin{abstract}
Shoplifting is a major issue in Canada, with 87 percent of small and medium sized stores victimized each year. As a result, shopkeepers face a difficult decision between allowing this loss of product, or detaining the individual and facing tortious liability for an unlawful arrest. The legal debate regarding allowing a shopkeeper's privilege to detain an individual, when they have reasonable suspicion of theft, attempts to balance competing values of personal liberty and the protection of property. Due to the changing context surrounding this issue, the Ontario Superior Court of Justice recently endorsed the shopkeeper's privilege in Mann v. Canadian Tire Corporation Ltd. In Mann, Justice Akhtar drew on existing Canadian, American, and United Kingdom jurisprudence to articulate a new test for shopkeeper's privilege in Canada.
\end{abstract}

\section{TABLE OF CONTENTS}

I. INTRODUCTION . . . . . . . . . . . . . . . . . . . . . . . . . . . . . . . . 29

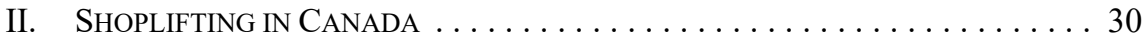

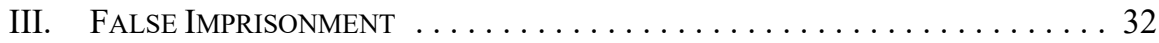

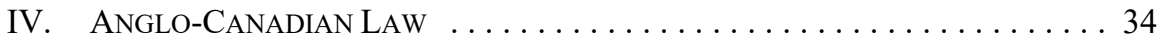

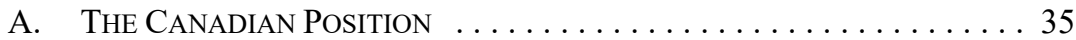

V. AMERICAN LAW ......................... 41

A. Judicial DEVELOPMENTS $\ldots \ldots \ldots \ldots \ldots \ldots \ldots \ldots \ldots \ldots \ldots \ldots$

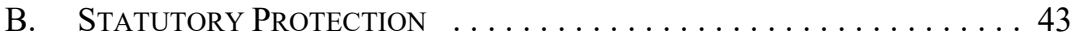

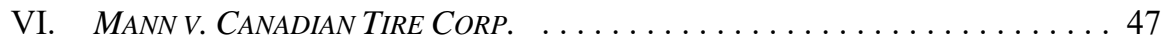

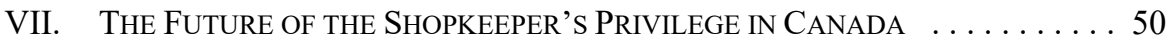

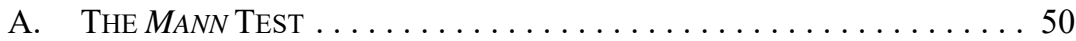

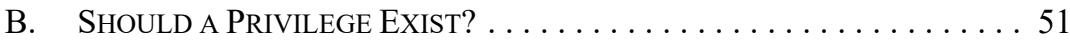

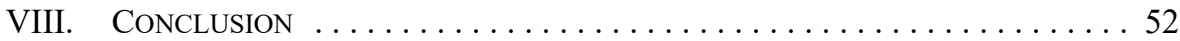

\section{INTRODUCTION}

Canadian shopkeepers frequently face the following dilemma. The circumstances suggest that an ostensible customer is actually a shoplifter. The police could be called, but they will arrive far too late unless the suspect is detained. Detention, however, carries substantial risks. Aside from the fact that intervention may entail physical injury or death, ${ }^{1}$ a shopkeeper's power of arrest depends on the actual commission of a crime. There is no leeway for

Professor, Faculty of Law, University of Alberta.

BA, Vancouver Island University; JD candidate 2019, Alberta.

Those dangers were tragically illustrated at a shopping mall in Edmonton on 17 April 2018. Sixty-oneyear-old Iain Armstrong was severely beaten while attempting to prevent a theft from another merchant's kiosk. He succumbed to his injuries three days later. See "Homicide Detectives Take Over Southgate Centre Case After Victim Dies in Hospital," Edmonton Journal (20 April 2018), online: $<$ https://edmontonjournal.com/news/crime/badly-beaten-victim-in-southgate-centre-attack-dies $>$. For the purposes of this article, the circumstances leading to Iain Armstrong's death raise two interesting points. First, as commonly formulated, the shopkeeper's privilege applies only if it appears that the merchant's own goods are being stolen. Second, while arguably too narrow in other respects, the Criminal Code may tolerate mistakes that are made in the apprehension of a person who appears to be escaping from the fresh pursuit of a person who holds a power of arrest (Criminal Code, RSC 1985, c C-46, s 494(1)(b)). These points are discussed below. 
mistakes. Consequently, even if the merchant had probable cause for believing that a theft was in progress, a wrongfully detained customer will be entitled to sue for false imprisonment. Hence the dilemma: allow an apparent thief to walk away scot-free or run the risk that an unauthorized arrest will result in tortious liability.

While that dilemma remains in most Canadian jurisdictions, a trial court in Ontario recently endorsed the American doctrine of a shopkeeper's privilege or merchant's privilege. $^{2}$ As Justice Akhtar explained in Mann v. Canadian Tire Corporation Ltd., ${ }^{3}$ the commercial, cultural, and philosophical conditions that historically valued personal liberty above property rights have changed. Current conditions, he found, support recognition of a carefully drawn and narrowly confined immunity for errors. A shopkeeper who has probable grounds for believing that a theft is being (or has been) committed is entitled to detain the suspect - in a reasonable manner and for a reasonable time — for the sole purpose of investigating the situation. This article examines that development.

The discussion is divided into six parts and a conclusion. Part II sets the scene with a short survey of shoplifting in Canada. Part III provides a brief summary of the tort of false imprisonment. Part IV explains the traditional Anglo-Canadian rules governing citizens' arrests. Part V outlines the shopkeeper's privilege that has been developed by American courts and legislatures. Part VI examines the decision in Mann. And Part VII considers the implications of providing Canadian merchants with an immunity for reasonable errors. In the final analysis, recognition of the new defence is warranted, but it should be introduced legislatively rather than judicially.

\section{SHOplifTing in CANADA}

Given human nature, it seems safe to assume that the concept of theft originated very shortly after the first successful assertion of property ownership. The sub-species of shoplifting, in contrast, is a more recent phenomenon. Its defining feature - the theft of goods from a retailer - presumes a certain form of commerce. The word consequently did not regularly appear in print until the seventeenth century, when merchants in London began to display their wares in windows and display cases. Outraged by the number of women ${ }^{4}$ who availed themselves of the opportunity to take without paying, shopkeepers successfully lobbied Parliament to pass the Shop-Lifting Act in $1699 .{ }^{5}$ Typical of the times, the statutory sanctions were harsh. Those convicted of stealing property worth more than five shillings were subject to hanging or "transportation" to North America or Australia. Less ambitious offenders were liable to have their hands or faces branded with hot irons.

The terms are used interchangeably.

2016 ONSC 4926 [Mann].

Originally, the offence was an overwhelmingly female phenomenon. See Shelley Tickell "Shoplifting in Eighteenth-Century London: A Source for Female Retailing?" (2015) 1:3 History Retailing \& Consumption 172.

(UK), 1699, 10 \& 11 Wm III, c 23 (1699). 
A second retail revolution greatly exacerbated the problem. Goods were historically kept behind counters. A customer would present a list; the merchant would fetch the items from the back and take payment before handing over the goods. In such circumstances, shoplifting was difficult. Around the turn of the twentieth century, however, merchants responded to an increasingly consumerist society by introducing self-serve stores. ${ }^{6}$ As remains true today, a customer collects items while wandering the aisles and then pays a cashier located near the exit.

That innovation proved enormously successful, but it also had legal implications. ${ }^{7}$ Most obviously, it greatly increased the possibility of theft. Shoplifters had easy access to goods. By extension, as they more frequently encountered suspected thieves, merchants were put to a difficult decision: do nothing and risk the loss of goods, or effect arrests and risk the imposition of tortious liability. As discussed below, American law responded to the situation by providing merchants with an immunity for reasonable errors. Anglo-Canadian courts, in contrast, continued, as a matter of policy or indifference, to prefer personal liberty over property rights.

The size of the problem should not be underestimated. Canadian retailers lose more than $\$ 4,000,000,000$ per year - nearly $\$ 11,000,000$ per day - to theft. ${ }^{8}$ It has been estimated that 87 percent of small and medium-sized stores are victimized each year, while a large retailer can expect to be hit 15 to 20 times a day. ${ }^{9}$ The associated costs, of course, are normally passed on to consumers. For the average Canadian household, the annual burden is about $\$ 200$, even before the expense of theft-prevention programs are factored into the equation. $^{10}$

The details of retail theft in Canada span a broad range. Easily hidden items are obviously attractive, but thieves also target goods that can be readily sold online: cosmetics, razors, teeth whiteners, batteries, and so on. ${ }^{11}$ The human side of the phenomenon is similarly varied. ${ }^{12}$ One study indicated that 80 percent of Americans have shoplifted at least once and

Today it may be difficult to even imagine the concept as a novelty, but in 1917, Clarence Saunders was granted a patent for the idea of a "self-service store." The Piggly Wiggly, which he founded, is now one of America's leading grocery chains. See Mike Freeman, Clarence Saunders \& the Founding of Piggly Wiggly: The Rise \& Fall of a Memphis Maverick (Charleston, SC: History Press, 2011) at 23.

Pharmaceutical Society of Great Britain v Boots Cash Chemists (Southern) Ld, [1953] 1 QB 401 (CA) is commonly cited for the distinction between offers and invitations to treat. First-year students often struggle with the case because it appears to involve a dry regulatory dispute regarding the need for "poisons" to be sold under the supervision of pharmacists. Interest levels drop further when the "poisons" are revealed to be generally innocuous medicines that are available without prescription. The discussion generally turns, however, when the facts are re-presented as a contest between competing business models. If "poisons" could be sold by self-service general stores (as exist today), the claimant society feared for the survival of stand-alone "chemists" that operated on the traditional model.

$8 \quad$ Retail Council of Canada \& PwC, Securing the Bottom Line: Canadian Retail Security Survey 2012 (Toronto: Retail Council of Canada, 2012) at 3, 7 [RCC, Securing the Bottom Line].

9 Retail Council of Canada \& RBC, Retail Business Security Self Assessment (Toronto: Retail Council of Canada, 2008) at 2; St John Alexander \& Kendra Mangione, "To Catch a Thief: Metro Vancouver Stores Reveal How They Catch Shoplifters," CTV News (14 February 2017), online: <https://bc.ctvnews.ca/tocatch-a-thief-metro-vancouver-stores-reveal-how-they-catch-shoplifters-1.3285783>. Jane Macdougall "There's No Such Thing as a Free Puffy Jacket: The Price We All Pay for Shoplifters," National Post (5 January 2013).

RCC, Securing the Bottom Line, supra note 8 at 19; Alexander \& Mangione, supra note 9.

A study conducted in Ontario in 2014 revealed some demographic differences. See Forum Research Inc, News Release, “As Many as a Quarter Have Shoplifted” (20 December 2014) at 1, online: <poll.forum research.com/data/ON\%20Shoplifting\%20News\%20Release $\% 20(2014 \% 2012 \% 2020) \% 20$ Forum $\% 20$ Research.pdf $>$. Shoplifting was found to be somewhat more common among males than females (18 
10 percent do so frequently - numbers that the author posited for Canada as well. ${ }^{13}$ To a surprising extent, however, retail theft is also an inside job. Between 2008 and 2012, the amount of theft attributed to employees rose from 19 percent to 33 percent. $^{14}$

For present purposes, the details are interesting insofar as they provide context, but it is the sheer size of the problem that is more important. Increasingly sophisticated theft detection strategies may reduce the risk of error, but the simple volume of shoplifting ensures that shopkeepers will continue to face the twin perils of stolen stock and legal liability.

\section{FALSE IMPRISONMENT}

Because the merchant's privilege primarily serves as a defence to claims of false imprisonment, a brief sketch of that tort is required. The following summary focuses on issues likely to affect suspected shoplifters.

A false imprisonment occurs when the defendant directly and without justification imposes a total restraint on the plaintiff's freedom of movement. ${ }^{15}$ That definition raises several important points.

The restraint must be total. Liability will not lie if the defendant barred some pathways, but left another open. ${ }^{16}$ The tort is committed, however, if the only means of egress is unreasonably difficult or dangerous. ${ }^{17}$ Moreover, while the restraint must be total, it need not be lengthy; a momentary detention, beyond de minimis, is actionable. ${ }^{18}$ It may even be possible to incur liability for detaining people without their knowledge, as when an unconscious individual is placed in a locked room. ${ }^{19}$

While the restraint must be complete, it need not be physical ${ }^{20}$ Very commonly, especially in cases involving suspected shoplifters, the claimant is prevented from leaving by psychological forces. ${ }^{21}$ A court will ask whether the threat of physical force or the assertion of legal authority would induce a reasonable person in the plaintiff's circumstances to believe

percent to 12 percent), nearly three times as common for young adults as compared to senior citizens (22 percent to 5 percent), and increasingly common as one moves left on the political spectrum (Progressive Conservative $=12$ percent, Liberal $=13$ percent, New Democrat $=19$ percent, Green $=$ 24 percent) (ibid at 3). The study's author concluded, as a general proposition, that shoplifting "is a young person's game, and that's a proxy for New Democrats, Greens and the non-religious" (ibid at 1). A Blicq, "The Secret World of Shoplifting" (2009) at 00h:03m:43s-00h:03m:56s, online: <https:// archive.org/details/TheSecretWorldOfShoplifting $>$.

RCC, Securing the Bottom Line, supra note 8 at 8.

GHL Fridman, The Law of Torts in Canada, 3rd ed (Toronto: Carswell, 2010) at 65.

Bird v Jones (1845), 7 QB 742 at 755 [Bird]; Hanson v Wayne's Café Ltd (1990), 84 Sask R 220 at para $8(\mathrm{QB})$.

Cf Wright $v$ Wilson (1699), 1 Ld Raym 739 (the only means of exit required the plaintiff to trespass on a third party's property - no false imprisonment).

Banyasz v K-Mart Canada Ltd (1986), 57 OR (2d) 445 at 446-48 (H Ct J (Div Ct)) [Banyasz].

Murray $v$ Ministry of Defence, [1988] 1 WLR 692 at 698 (HL).

Of course, liability may lie if the defendant did imprison the plaintiff through physical force: Chopra v T Eaton Co, 1999 ABQB 201 [Chopra]; Briggs v Laviolette (1994), 21 CCLT (2d) 105 (BCSC) [Briggs]; Kendall v Gambles Canada Ltd (1981), 11 Sask R 361 (QB) [Kendall]. It is possible that liability for false imprisonment may arise if the defendant allowed the plaintiff to walk away, but held possession of something or someone precious to the claimant: Ashland Dry Goods Co $v$ Wages, $195 \mathrm{SW}$ (2d) 312 (Ky CA 1946).

$21 \quad$ Mann, supra note 3; Higgins v Macdonald, [1928] 4 DLR 241 (BCCA) [Higgins]; Campbell v SS Kresge Co Ltd (1976), 74 DLR (3d) 717 (NS SC (TD)); cf Cannon v Hudson's Bay Co, [1939] 4 DLR 465 (BCSC). 
that movement was barred. That requirement is frequently satisfied by a combination of factors - for example, a clanging alarm, the attention of uniformed security personnel, a growing crowd of gawking bystanders, and a demand to discuss the matter in a back room. Unfamiliar with the law and raised in a culture of conciliatory cooperation, few Canadians are likely to assert their rights and walk away despite the risk of escalating the legal, physical, and psychological costs. That is particularly true of those who can easily establish their innocence.

As a species of the writ of trespass, false imprisonment requires proof of directness. ${ }^{22}$ Although that element is often ignored or overlooked, a court should ask whether the plaintiff's injury was a direct result of the defendant's conduct. That test is easily satisfied if, for instance, a merchant grabs a suspect by the elbow, but the analysis is complicated if a police officer acts after talking to a shopkeeper. A court should then ask whether the officer made the decision to arrest (no directness between merchant and suspect) ${ }^{23}$ or whether the shopkeeper effectively chose the course of action but proceeded through the officer's agency (directness established). ${ }^{24}$

The plaintiff bears responsibility for the preceding elements, but the issue of justification falls to the defendant. ${ }^{25}$ In the current context, that means that a claim will fail if the court is satisfied that the impugned acts were legally authorized by the common law rules regarding citizen's arrests, section 494 of the Criminal Code provisions, ${ }^{26}$ or perhaps the shopkeeper's privilege. Those possibilities are discussed below. ${ }^{27}$

Finally, if liability is imposed, damages may be awarded under various heads. As a form of trespass, false imprisonment is actionable per se. ${ }^{28}$ Even if the tort did not inflict any calculable loss, nominal damages are available. Typically, of course, the plaintiff seeks compensatory damages. ${ }^{29}$ If the defendant's high-handed or abusive conduct additionally led the plaintiff to suffer insult, indignity, or humiliation, this head may extend to aggravated damages, which provide compensation for such injuries. ${ }^{30}$ And if the defendant's conduct is so bad as to warrant punishment and deterrence, the court may award punitive damages on top of other measures of relief. ${ }^{31}$

Foth v O'Hara (1958), 15 DLR (2d) 332 (Alta SC).

Webster v Edmonton Chief of Police, 2005 ABQB 142, 374 AR 319 at para 59, rev'd on other grounds 2007 ABCA 23; Brule v Chmilar, 2000 ABQB 9.

Lebrun v High-Low Foods Ltd (1968), 69 DLR (2d) 433 (BCSC) [Lebrun]; Hanisch v Canada, 2004 BCCA 539; Valderhaug v Libin (1954), 13 WWR 383 (Alta CA).

Dendekker v FW Woolworth Co Ltd, [1975] 3 WWR 429 at 432 (Alta SC) [Dendekker]; Freyv Fedoruk, [1950] SCR 517 at 523.

Supra note 1, s 494.

See Parts IV, IV.A.1.b, and VI, below.

As discussed in Part VI, below, that may have been the end result in Mann, supra note 3 at para 83.

Trew v 313124 Saskatchewan Ltd, 2005 SKQB 79; Kennedy v Tomlinson (1958), 13 DLR (2d) 734 (Ont H Ct), rev'd on other grounds (1959), 20 DLR (2d) 273 (Ont CA); cf Kalsi v Greater Vancouver Associate Stores Ltd, 2009 BCSC 287 ("nominal damages" of \$6,500 at para 326).

Bahner v Marwest Hotel Co Ltd (1969), 6 DLR (3d) 322 (BCSC), aff'd (1970), 12 DLR (3d) 646 (BCCA) [Bahner]; Muir v Alberta (1996), 132 DLR (4th) 695 (Alta QB); Jeeves (Guardian of) $v$ Swanson, 1995 CanLII 520 (BCSC).

Nagy v Canada, 2006 ABCA 227; Chopra, supra note 20 at paras 222, 234; Bahner, ibid. 


\section{Anglo-Canadian Law}

The common law right to arrest without warrant is long settled, but somewhat complex. Originally, there was generally no distinction drawn between the powers of a peace officer and those of private citizen. Neither could arrest on the basis of a misdemeanour, but both were entitled to act upon a breach of the peace or its immediate aftermath. For present purposes, however, it is the rules regarding felonies that matter most.

Historically, both peace officers and private citizens were entitled (and in many instances required) to arrest those who committed felonies, ${ }^{32}$ but neither group enjoyed any leeway for errors. ${ }^{33}$ Even if the circumstances provided probable cause for an honest belief that a crime had occurred, intervention triggered tortious liability unless the arresting party could prove that a felony had actually been committed. Around the turn of the nineteenth century, however, English society dramatically changed. Industrialization increased urbanization, and the dissolution of traditional bonds led to rampant criminality. ${ }^{34}$ There was a great desire for order and protection. Accordingly, as part of the broader trend toward specialization, Sir Robert Peel introduced professional police (called "Bobbies" in his honour) to London. ${ }^{35}$ The courts acted along similar lines. While private citizens remained restricted to arresting for actual felonies, a peace officer was entitled to act on a reasonable belief that a felony had been committed. ${ }^{36}$ It made sense to encourage intervention by those trained for the task.

Police officers continue to enjoy that power in England today. The rules governing private citizens have been softened only slightly. ${ }^{37}$ Walters v. W. H. Smith \& Son Ltd. ${ }^{38}$ is authoritative. The plaintiff worked for the defendant bookshop, but in violation of his employment terms, he also operated his own book store. After discovering a pattern of missing stock, the defendant surreptitiously marked all of its copies of a particular book. When one of the copies disappeared, the defendant went to the plaintiff's own business, where the missing book was found. The defendant apprehended the plaintiff and caused him to be charged with the theft of the marked book, but not with any of the other losses. Somewhat remarkably, however, the plaintiff managed to persuade the criminal jury that while he did take the book, he had not stolen it because he had intended to pay for it at some later date.

Encouraged by that success, the plaintiff sued for false imprisonment. The defendant had to accept that the marked book had not been stolen, but it resisted liability by arguing that some thefts had occurred (namely in connection with its other losses) and that it reasonably believed that the plaintiff was responsible. A paucity of case law necessitated reliance on commentators and ancient Year Books, but Chief Justice Sir Rufus Isaacs felt confident in

Statute of Westminster 1285, 13 Edw, c 4.

Jerome Hall, "Legal and Social Aspects of Arrest Without a Warrant" (1936) 49:4 Harv L Rev 566.

Lord Mansfield, who decided a number of leading cases regarding the powers of arrest, lost his home — and nearly his life - to a rampaging mob during the Gordon Riots of 1780: Samuel v Payne (1780), 1 Doug 359 (KB) [Samuel]; Ledwith v Catchpole (1783), Cald 291 (KB).

Metropolitan Police Act, 1829 (UK), 10 Geo IV, c 44.

Samuel, supra note 34; Lawrence v Hedger (1810), 3 Taunt 14 (KB); Beckwith v Philby (1827), 6 B \& C 635 (KB).

The private citizen's powers of arrest were the subject of later legislation: Police and Criminal Evidence Act 1984 (UK), c 60, s 24A.

(1913), [1914] 1 KB 595 [Walters]. 
stating the law. The opening premise was clear: "[i]nterference with the liberty of the subject, and especially interference by a private person, has ever been most jealously guarded by the common law." ${ }^{39}$ For that reason, a private citizen cannot arrest unless a felony has actually been committed. If that requirement has been satisfied, however, an error of identity may be forgiven. The citizen is entitled to apprehend the person believed, on reasonable grounds, to have committed the offence. ${ }^{40}$

While conceding that the "law seem[ed] to operate somewhat harshly" Court held that the defendant did not fall within that rule. Despite being "genuinely convinced after reasonable inquiry that [the claimant was] the perpetrator of the crime, [the defendant was] mistaken." 42 The broader story may well have involved felonies, but since the plaintiff had not committed the specific crime for which he had been apprehended, the arrest was unjustified and the defendant was liable for false imprisonment.

\section{A. The Canadian Position}

The common law, as represented by Walters, provides the backdrop to the Canadian position on arrests without warrants:

- $\quad$ Police Officers: An arrest may be made by a police officer who believes on reasonable and probable grounds that the detainee has committed an indictable offence or is about to do so. ${ }^{43}$

- $\quad$ Private Citizens: A private citizen — including a shopkeeper or a security guard ${ }^{44}$ - may be forgiven a mistake as to an offender's identity, but not an error as to the crime's existence. ${ }^{45}$ Accordingly, if merchandise has been stolen, then the person reasonably believed to be responsible may be apprehended. ${ }^{46}$ In contrast, if no crime has been committed, then there is no power of arrest, even if the merchant had probable cause for believing otherwise.

$39 \quad$ Ibid at 602.

Ibid.

Ibid at 606 .

Ibid at 607.

Police also possess other powers unrelated to the issue of shoplifting - for example, the power to arrest a person believed on reasonable and probable grounds to be involved in a breach of the peace: Criminal Code, supra note 1, s 31(1).

44 Security guards are classified as private citizens rather than peace officers: Banyasz, supra note 18 at 447; Dendekker, supra note 25 at 435. If a security guard commits the tort of false imprisonment, liability will normally extend vicariously to the merchant employer: Chopra, supra note 20 at para 146; cf Dendekker, ibid at 438 (merchant retained services of independent company that employed security guard - merchant not vicariously liable for guard's tort).

45 McKenzie v Gibson (1850), 8 UCR 100 at 101-102 (QB); Williams v Laing (1923), 55 OLR 26 at 28 (SC AD); Sears Canada Inc v Smart (1987), 36 DLR (4th) 756 (Nfld CA) [Sears]; Hayward v FW Woolworth Co Ltd (1979), 23 Nfld \& PEIR 17 at para 52 (Nfld SC (TD)) [Hayward]; Chopra, ibid at para 109; Mann, supra note 3 at paras 30-36. A slim line of authority holds that a private citizen who acts on reasonable and probable grounds may be forgiven errors regarding both the identity of a culprit and the existence of a crime: Karogiannis v Poulus (1976), 72 DLR (3d) 253 (BCSC) [Karogiannis]; Hucul v Hicks (1965), 55 DLR (2d) 267 (Sask QB) [Hucul]. That view, however, is contrary to the historical precedents, unsupported by subsequent judgments, and premised on the court's willingness to judicially re-write the Criminal Code: Kendall, supra note 20 at para 72; Hayward, ibid at para 60. That issue is discussed in Part IV.A.1.b.ii, below.

46 The discussion is limited to situations arising from the theft of goods. Private citizens also have a power to arrest in connection with breaches of the peace: Chopra, ibid at para 109. 
Canadian courts have acknowledged that those rules continue to fall heavily on shopkeepers. ${ }^{47}$ Granted, the use of theft detection devices and security personnel may reduce errors. Moreover, if litigation does occur, the commission of an indictable offence need merely be established, under the usual civil standard, to a balance of probabilities. ${ }^{48}$ The central dilemma nevertheless remains: in the event of doubt, merchants must risk either losing goods or being held legally liable.

\section{CRIMINAL CODE}

Powers of arrest are addressed by the Criminal Code. ${ }^{49}$ The legislation largely mirrors the common law, but the two regimes differ in some respects, sometimes substantially. Consequently, it is important to appreciate that the statutory provisions were not intended to codify or replace the judge-made laws. ${ }^{50}$ The accused may invoke either set of rules.

A discussion of the legislation must be prefaced with a caveat. Canadian courts routinely rely on the Criminal Code in deciding whether shopkeepers are justified in detaining suspected shoplifters. Is that practice appropriate? Two issues arise. The first is constitutional: given that tort law is a matter of provincial authority, ${ }^{51}$ what are the implications of resolving disputes on the basis of federal legislation ${ }^{52}$ The second issue is substantive: given that criminal law and tort law are animated by different concerns, pursue different purposes, and generate different sanctions, should rules designed to justify otherwise criminal conduct similarly immunize acts that would otherwise trigger civil liability? It might be argued, for instance, that the law should take a more forgiving attitude toward merchants when the feared outcome involves imprisonment rather than mere damages. Conversely, it may be argued that while tort law's goals are best achieved by a narrowly confined and fact sensitive merchant's immunity, the objectives underlying criminal law demand an approach that broadly errs on the side of a suspected shoplifter's liberty.

\section{a. Peace Officers}

The Criminal Code, like the common law, draws a fundamental distinction based on status. Section 495(1) states that a peace officer may arrest without warrant (a) a person who

Banyasz, supra note 18; Briggs, supra note 20 at para 16; Newhook v K-Mart Canada Ltd (1991), 116 Nfld \& PEIR 102 at para 93 (Nfld SC (TD)) [Newhook].

Hayward, supra note 45 at para 69; Kovacs v Ontario Jockey Club (1995), 126 DLR (4th) 576 at 593 (Ont Gen Div) [Kovacs]; Dendekker, supra note 25 at 432-33. The detention may be justified even if the plaintiff — as accused in the criminal matter — avoided prosecution or obtained an acquittal: Newhook, ibid at para 98.

Supra note 1. This discussion is limited to the powers of arrest that are most relevant for shopkeepers. A variety of statutes, both provincial and federal, deal with the rights of detention in other contexts: see e.g. Immigration and Refugee Protection Act, SC 2001, c 27, ss 55, 82.2(1); Canada National Marine Conservation Areas Act, SC 2002, c 18, s 21; Mental Health Act, RSA 2000, c M-13, Part 2; Trespass to Property Act, RSO 1990, c T.21, ss 9-10; Youth Justice Act, SNS 2001, c 38, s 14.

Mann, supra note 3 at para 37; Kovacs, supra note 48 at 591; Hayward, supra note 45 at para 66; Briggs, supra note 20 at para 15 . Section 8 of the Criminal Code, supra note 1 states: "[e]very rule ... of the common law that renders any circumstance a justification for ... a defence to a charge continues in force."

Constitution Act, 1982, being Schedule B to the Canada Act 1982 (UK), c 11, ss 91(27) (criminal law), 92(13) (property and civil rights).

Briggs, supra note 20 at para 11 . 
has committed an indictable offence, or a person whom the officer believes, on reasonable grounds, has committed — or is about to commit — an indictable offence, or (b) a person whom the officer finds committing any criminal offence.$^{53}$ Other than observing that the first set of possibilities is limited to indictable offences while the second encompasses all criminal offences, there is little that requires comment.

\section{b. Private Citizens}

Section 494, which governs arrests by private citizens, is more complicated. Three issues require close examination. ${ }^{54}$

\section{i. $\quad$ General Provision}

The common law rule, it will be recalled, requires the actual commission of a felony, but forgives reasonable mistakes of identity. Taken at face value, section 494(1) is narrower in scope:

Any one may arrest without warrant

(a) a person whom he finds committing an indictable offence; or

(b) a person who, on reasonable grounds, he believes

(i) has committed a criminal offence, and

(ii) is escaping from and freshly pursued by persons who have lawful authority to arrest that person. $^{55}$

Section 494(1)(a) is doubly restrictive. The person making the arrest must personally find the accused actually committing an indictable offence. The provision makes no allowance for mistakes and it does not permit intervention on the basis of information supplied by a third party.

Section 494(1)(b) is more forgiving, but it is restricted to a very specific sequence of events. Errors of perception are excused as long as they are supported by reasonable grounds. ${ }^{56}$ The circumstances, however, must at least appear to involve another person who possesses a power of arrest and is in fresh pursuit of an individual who, having committed a criminal offence, is escaping apprehension. While exceptions exist, ${ }^{57}$ that concatenation of events seldom occurs. For instance, neither part of section 494(1) would have sanctioned an arrest on the facts of Walters. ${ }^{58}$ As will be recalled, ${ }^{59}$ at the time of apprehension, the accused was neither found committing a crime nor escaping fresh pursuit.

Criminal Code, supra note 1, s 495(1). Though less relevant for the current discussion, section 495(1)(c) also permits an arrest if a peace officer believes on reasonable grounds that an individual is the subject of a warrant.

54 Other issues exist, but are less significant for present purposes. Criminal Code, ibid, section 494(3), for instance, states that a private citizen who has made an arrest must "forthwith deliver the person to a peace officer."

$55 \quad$ Criminal Code, ibid, s 494(1).

$56 \quad R v$ Volker, [1994] BCJ No 3134 (QL) (PC); $R$ v Dance, [1999] OJ No 5500 (QL) at para 40 (Sup Ct J); $R v$ McConville, 2005 BCPC 280; cf R v Buckland, [2003] OJ No 5777 (QL) (Ct J).

57 For both a successful and an unsuccessful invocation of section 494(1)(b), see Kendall, supra note 20 at para 74 .

$58 \quad$ Supra note 38.

59 See Part IV, above. 


\section{ii. $\quad$ Section 25(1)}

Because section 494(1)(a) provides no room for error and consequently has the capacity to create hardship, Canadian courts have occasionally tried to introduce an element of forgiveness. That strategy typically turns on section 25(1) of the Criminal Code:

Every one who is ... authorized by law to do anything in the administration or enforcement of the law

(a) as a private person ...

is, if he acts on reasonable grounds, justified in doing what he is required or authorized to do and in using as much force as is necessary for that purpose. ${ }^{60}$

Opinion is divided regarding the impact that section 25(1) has on section 494(1). One line of authority holds that section 25(1) provides a margin of error. That position was taken in Sears. ${ }^{61}$ A security guard in a department store observed a young man named Murphy acting suspiciously. Two other young men were observed nearby - the plaintiff allegedly made head gestures, while his friend actually talked with Murphy. All three were apprehended, detained, and handed over to the police. Stolen goods were found on Murphy, but not on the others. Charges were filed but the prosecution against the plaintiff was later withdrawn. He then sued for false imprisonment. Liability depended on whether the security guard's actions toward the claimant were justified. Justice Gushue held that section 494(1) requires proof that a crime was actually committed, but interpreted section 25(1) so as to immunize errors of identification arising from reasonable and probable grounds. ${ }^{62} \mathrm{He}$ explained that view on the bases that (1) the law would otherwise "place an almost impossible burden on" 63 shopkeepers, and (2) Parliament intended for sections 494(1) and 25(1) to replicate the common law rule that forgives reasonable mistakes of identity. Returning to the facts, he found that while Murphy had committed an indictable offence, the circumstances did not reasonably support the security guard's belief that the claimant was in cahoots with the thief. The Court accordingly upheld the trial judge's decision to award damages of $\$ 1,000$.

Dendekker $^{64}$ went one step further. The plaintiff bought two discount brassieres but regretted the purchase when she got home. She consequently placed the items in a paper bag and returned to the store the next day. After selecting a different brassiere, she compared it to the originals and then exchanged the items at the customer service desk. Unfortunately, two security guards misinterpreted the events, concluded that the paper bag contained stolen goods, and arrested the woman as she tried to leave the store. She successfully defended a criminal charge and sued for false imprisonment. The lack of an actual crime defeated the defendants' invocation of the common law defence, but the Court found that the "combined effect" of section 25(1) and the Criminal Code's provisions on warrantless arrests was a "'reasonable and probable grounds' defence." 65

Criminal Code, supra note 1, s 25(1).

Sears, supra note 45.

Sears, ibid. See also Briggs, supra note 20 at para 18.

Sears, ibid at 761.

Supra note 25.

Ibid at 434. 
Justice Shannon based that decision on a case ${ }^{66}$ involving section $495(1)$ (b) of the Criminal Code, which states that a peace officer may arrest "a person whom he finds committing a criminal offence." ${ }^{67}$ Because of the desirability of protecting officers acting in good faith, and because an officer at the time of arrest can never really know that a crime has been committed, section 25(1) was held to cause section 495(1)(b) to effectively say that a peace officer can arrest a person he finds apparently committing an offence. ${ }^{68}$ Justice Shannon reasoned that since section 495(1)(b) (for peace officers) and section 494(1)(a) (for private citizens) are identical, section 25(1) must similarly justify the arrest of a person whom a private citizen finds apparently committing a criminal offence. In either case, however, section 25(1) requires proof that the party making the arrest had "reasonable grounds" for believing that a crime was being committed. ${ }^{69}$ That was not true on the facts of Dendekker. And since it had been unreasonable for the guards to accuse the plaintiff of theft, their actions were unjustified and they were liable for false imprisonment.

The Criminal Code was similarly re-written on several occasions,${ }^{70}$ including shoplifting cases. ${ }^{71}$ The prevailing view nevertheless insists on taking section 494(1)(a) at face value. The citizen's power of arrest consequently is available only if one finds a person actually committing an indictable offence. Reasonable mistakes are not forgiven. The Criminal Code was introduced in 1892 and restated in 1906, 1927, 1955, and 1970. On each occasion, a plain reading of the relevant provisions reflected the traditional distinction between peace officers and private citizens. And yet, if section 494(1)(a) was read as if a power of arrest could be exercised over anyone found apparently committing an indictable offence, private citizens would enjoy the same broad authority that peace officers enjoy under section 495(1)(a). Moreover, on the issue of shoplifting, there would be a substantial shift toward property rights and away from personal liberty. And finally, it would be necessary to believe that Parliament intended to introduce all of those fundamental changes purely by implication. "T2 "This just cannot be." 73

Once the radical reading is rejected, section 25(1) has a limited impact. "Its purpose is not to empower but to protect; it is a shield not a sword."74 If a person is found committing an indictable offence, such that a power of arrest exists under section 494(1)(a), then a citizen is justified in proceeding "and in using as much force as is necessary" if "he acts on reasonable grounds." 75 Section 25(1), in other words, provides a defence for acts that would otherwise trigger tort liability. ${ }^{76}$

Reid v DeGroot (1963), 40 DLR (2d) 867 (NSSC) [Reid].

Criminal Code, supra note 1, s 495(1)(b).

Reid, supra note 66 at 881.

Dendekker, supra note 25.

$R v$ Biron, [1976] 2 SCR 56 (Laskin CJC, Spence \& Dickson JJ dissenting). See also Wiltshire v Barrett, [1966] 1 QB 312, Denning MR (CA).

Hucul, supra note 45; Lebrun, supra note 24; Karogiannis, supra note 45.

If Parliament had wanted to forgive reasonable mistakes under section 494(1)(a), it could have expressly done so, as it did for section 494(1)(b). By wording the provisions differently, the legislators must have intended them to operate differently.

Kendall, supra note 20 at para 67.

Ibid at para 68 .

Chopra, supra note 20 at para 143; Hayward, supra note 45 at para 63; Dandurand $v$ Pier 1 Imports (Canada) Inc (1986), 55 OR (2d) 329 (CA); Newhook, supra note 47; Cronk v FW Woolworth (1986), 44 Sask R 81 (QB); Banyasz, supra note 18.

Eccles v Bourque, [1975] 2 SCR 739 at 742, Dickson J; Kovacs, supra note 48 at 590. 


\section{iii. The Lucky Moose}

The Criminal Code's final provision regarding citizens' arrests provides special protection for property.

\footnotetext{
The owner or a person in lawful possession of property, or a person authorized by the owner or by a person in lawful possession of property, may arrest a person without a warrant if they find them committing a criminal offence on or in relation to that property and

(a) they make the arrest at that time; or

(b) they make the arrest within a reasonable time after the offence is committed and they believe on reasonable grounds that it is not feasible in the circumstances for a peace officer to make the arrest. $^{77}$
}

That provision temporally extends the power of arrest in connection with property crime. If a person is found actually committing such an offence, then the lawful possessor, owner, or agent is entitled to make an arrest. That power historically had to be exercised at the time of the crime, but in 2013 Parliament expanded the window of opportunity in response to events at The Lucky Moose. ${ }^{78}$ That case vividly illustrates some of the difficulties that merchants habitually experience.

The Lucky Moose is a grocery store owned and operated by David Chen in downtown Toronto. Chen grew increasingly frustrated by both the high incidence of shoplifting and the low level of interest exhibited by the police. On a spring day in 2009 , the store's video cameras captured images of Anthony Bennett — an incorrigible thief with 43 prior convictions - loading some plants on to the handlebars of his bike and riding away without paying. His patience exhausted, Chen was prepared when Bennett returned an hour later intending to steal a few more items. After a brief conversation, Bennett dropped his bike and ran. Chen, accompanied by two colleagues, caught up to the thief, bound his hands and feet, and called the police.

For Bennett, it was business as usual: he was arrested, charged, and convicted. The interesting twist occurred on the other side of the story. Upon arriving at the scene, the police handcuffed, strip-searched, and held Chen and his colleagues overnight. The three men were then charged with assault and false imprisonment. And indeed, on a plain reading of section 494(2) as it stood at the time, convictions probably should have followed. In 2009, the provision merely said that:

Any one who is

(a) the owner or a person in lawful possession of property, or

(b) a person authorized by the owner or by a person in lawful possession of property,

may arrest without warrant a person whom he finds committing a criminal offence on or in relation to that property. $^{79}$

Criminal Code, supra note 1, s 494(2).

$R v$ Chen, 2010 ONCJ 641 [The Lucky Moose].

Criminal Code, supra note 1, s 494(2) as it appeared on the date of the events: 23 May 2009. 
Because that provision said "finds" rather than "found," it required a tight temporal relationship between the two elements. The arrest had to follow immediately upon the crime, so as to constitute a single event. In The Lucky Moose, however, Chen and his colleagues arrested Bennett an hour after he had been found stealing plants. The crime was one episode; the arrest was another. Justice Khawly nevertheless acquitted the men on a very generous reading of the law and the facts. ${ }^{80}$ Bennett's return to the store was said to be a continuation of the same criminal act. He simply needed two trips to carry away everything he intended to steal.

The Court's strained interpretation allowed it to reach the desired result, but a slight change in facts would have precluded an acquittal. Suppose, for instance, that instead of coming back to victimize The Lucky Moose a second time, Bennett returned to the area in order to wait for a bus. If Chen spotted him and made an arrest, section 494(2) would clearly be inapplicable.

The notoriety of The Lucky Moose persuaded the government to act. ${ }^{81}$ In 2013, Parliament revised section 494(2) to allow an arrest to be made in connection with a property crime as long as the arrest occurs "within a reasonable time after the offence" and it is "believe[d] on reasonable grounds" that it is not feasible for a peace officer to act. ${ }^{82}$ Significantly, however, leeway is limited to the timing of the detention. The Criminal Code still does not forgive reasonable errors regarding either the commission of a crime or the identity of the culprit.

\section{AMERican LaW}

Notwithstanding fundamental changes in the retail world (for example, self-service stores and theft-detection devices), the ability of Canadian shopkeepers to apprehend suspected shoplifters has not fundamentally changed since the days of Lord Mansfield and Sir Robert Peel. The American experience has been far different. ${ }^{83}$

\section{A. Judicial DeVelopments}

The story begins with the traditional common law rule that prohibited innkeepers and common carriers from detaining customers who failed to pay. ${ }^{84}$ Possessory liens were available in some circumstances, but disputes between creditors and debtors generally had

80 The Lucky Moose, supra note 78.

Though his behaviour divided public opinion, David Chen was sufficiently well-regarded to receive a Diamond Jubilee Medal from Queen Elizabeth II in 2013. See online: <www.gg.ca/honour.aspx?id= $260094 \& \mathrm{t}=13 \& \mathrm{In}=$ Chen\#>.

82 Criminal Code, supra note 1, s 494(2).

83 The American law is exhaustively and expertly examined in JP Gilroy, The Law of Arrest for Merchants and Private Security Personnel (2014). The work, self-published to a very high standard, is available through online vendors. For an annotated summary of American law, see Robert A Brazener "Construction and Effect, in False Imprisonment Action, of Statute Providing for Detention of Suspected Shoplifters" (1973) 47 ALR 3d 998. Finally, a large number of articles address different aspects of citizen's arrest, including several devoted to shopkeepers: see e.g. Hall, supra note 33; "The Protection and Recapture of Merchandise from Shoplifters" (1952) 47 NWUL Rev 82; "Shoplifting and the Law of Arrest: The Merchant's Dilemma" (1953) 62:5 Yale LJ 788; Ira P Robbins, "Vilifying the Vigilante: A Narrowed Scope of Citizen's Arrest" (2016) 25:3 Cornell JL \& Pub Pol’y 557. 
to be resolved through civil litigation. ${ }^{85}$ Because that approach often ended in frustration, a thin line of authority developed to permit temporary detentions. ${ }^{86}$ There was no need to prove the actual commission of a crime; intervention was justified as long as it was reasonable in the circumstances. That meant, inter alia, that detention had to be exercised for the purpose of investigation and not with a view to compelling payment. And interestingly, given the focus of what followed, the new rule was not designed to allow title-holders to protect property by apprehending suspected thieves. The authorities dealt instead with performed services and consumed goods.

The crucial step in protecting merchants from potential shoplifters was taken in Collyer v. S. H. Kress Co ${ }^{87}$ Security guards employed by the defendant store believed that they saw the plaintiff stealing goods. He was taken to a back room, where a search revealed that he was indeed in possession of the allegedly stolen merchandise. He claimed, however, that he had previously purchased the items, thrown away the wrappings, and received no receipt. The security guards, the police, and the prosecutor were unimpressed, but a criminal jury bought the story and issued an acquittal on all charges. Buoyed by that success, the plaintiff sued the security guards for false imprisonment and won at trial. That decision, however, was overturned on appeal.

Writing for a unanimous California Supreme Court, Justice Thompson narrowly focused on the dilemma that a merchant experiences when it appears that a suspected shoplifter is actively engaged in theft. In "an effort to harmonize the individual right to liberty with a reasonable protection [of] property," he developed a new privilege: "where a person has reasonable grounds to believe that another is stealing his property ... he is justified in detaining the suspect for a reasonable length of time for the purpose of investigation in a reasonable manner." ${ }^{\prime 8}$ Accordingly, although the lack of an actual crime would have been fatal to any defence under the traditional common law rule, the security guards were justified in detaining the claimant.

Collyer is the single most important event in the development of a merchant's privilege. It held that as long as a shopkeeper reasonably believed that goods were being stolen, and reasonably detained the suspect for the purpose of investigation, then a claim for false imprisonment would fail even if no crime had actually occurred. The decision's stature grew further when it effectively was adopted, in 1965, as section 120A of the Restatement of the

Nonpayment for services may constitute a crime if, for instance, the customer intended to defraud the merchant from the outset. Moreover, that crime might be one for which a citizen was entitled to arrest without warrant. Detention for the purpose of extracting payment, however, has always been unlawful: Bergeron v Peyton, 82 NW 291 (Wis Sup Ct 1900).

$86 \quad$ Standish v Narragansett Steamship Co, 111 Mass 512 (Sup Jud Ct 1873); Jacques v Childs Dining Hall Co, 138 NE 843 (Mass Sup Jud Ct 1923).

8754 P (2d) 20 (Cal Sup Ct 1936) [Collyer].

$88 \quad$ Ibid at 23 . 
Law Second: Torts. ${ }^{89}$ Collyer consequently continues to be cited as the leading authority in the area.

The situation, however, is actually more complicated than those citations suggest. While its legacy is undeniable, Collyer's practical significance is less than commonly believed. Even on its own terms, the rule formulated in California was accepted in less than a third of the states, and it was explicitly rejected in several. ${ }^{90}$ Moreover, the rule was subsequently burdened with a frequently unworkable distinction between detention (which was permissible) and arrest (which was impermissible). ${ }^{91}$ Most significantly, the test articulated in Collyer, like most court-created rules, ultimately proved to be a mixed blessing. Flexibly amenable to judicial revision, it is also frustratingly incomplete. Collyer necessarily left many issues unaddressed, and because there is no end to the ways in which the competing values of personal liberty and private property can be balanced, conflicting decisions are common.

\section{B. Statutory Protection}

Collyer usefully illustrated the possibility of providing shopkeepers with better protection against shoplifting, but today, the power of detention is almost invariably addressed through legislation. All fifty states, plus the District of Columbia, have now provided merchants with a right to detain suspected shoplifters. ${ }^{92}$

Those statutes share certain basic features, but they differ widely on the details. The modest purpose of this section is two-fold: (1) briefly summarize the general nature of the shopkeeper's immunity, and (2) identify the sorts of issues that need to be addressed if Canadian law is to move in a similar direction.

\section{GENERAL FEATURES}

The precise language varies, but the statutes invariably require a merchant to act on probable cause. A mistake will be forgiven only if the circumstances, objectively assessed on the basis of information available to the merchant at the time of apprehension, appeared to involve theft. If the merchant acted on the basis of an employee's suspicions, then it is

The American Law Institute, Restatement of the Law: Second: Torts (2d), vol 1 (St. Paul, Minn: ALI, 1965) at 202:

One who reasonably believes that another has tortiously taken a chattel upon his premises, or has failed to make due cash payment for a chattel purchased or services rendered there, is privileged, without arresting the other, to detain him on the premises for the time necessary for a reasonable investigation of the facts.

That formulation carried over many features from Collyer - for example, detention must be exercised for the purpose of investigation and the privilege will be lost in the event of unreasonable behaviour. In other respects, however, the Restatement is broader or narrower than Collyer. In contrast to the judicial focus on actively protecting property rights, $\S 120 \mathrm{~A}$ applies in the context of both chattels and services. At the same time, the Restatement may be less generous insofar as it expressly requires the detention to occur on the merchant's premises.

For details, see Gilroy, supra note 83 at 347.

Cervantez v JC Penney Co, 595 P (2d) 975 (Cal Sup Ct 1979).

Citations appear at Gilroy, supra note 83 at 428-30. 
generally the employee's belief that is tested for probable cause. ${ }^{93}$ In any event, evidence must be adduced of the facts that created the mistaken perception - a sincere belief, in itself, is never sufficient.

Probable cause must be established with respect to both the possession of merchandise and a criminal intention. The latter is difficult to demonstrate without evidence of at least an attempt at improper concealment. Accordingly, the burden may not be met if, as a matter of convenience and conscience, a shopper places items in a reusable tote bag while wandering the aisles. ${ }^{94}$ So too, the mere act of passing through a check-out counter with a heavy bag of cat litter on the bottom rack of a shopping cart probably does not constitute probable cause. In a situation like that, the customer's failure to pay is as likely to be explained by innocent error as by criminal intention. ${ }^{95}$ Some statutes expressly deem a triggered theft detection device to be probable cause, but that conclusion may be overcome by evidence that the system frequently malfunctioned due to either mechanical defects or employee carelessness. $^{96}$

If probable cause exists, then a merchant may detain an individual, but only for the purpose of investigation. (If that investigation proves the actual commission of a crime, then a power of arrest exists even under the traditional common law rules.) The legislative goal, after all, is to protect property rights by allowing merchants to stop suspected shoplifters without fear of liability. That goal is served as long as a shopkeeper is authorized to determine whether a suspicion is well-founded. In contrast, no immunity is available if a suspect is held with a view to extracting a confession or signing a waiver of liability. ${ }^{97}$

Once a suspect is justifiably detained, the merchant must act reasonably. That is true with respect to both the manner and the duration of the detention. Physical force is permitted, but it must be commensurate with the circumstances. Potentially lethal force is never warranted in the protection of merchandise.$^{98}$ Likewise, a shopkeeper should be straightforward and forceful, but there is never any call for deliberately rude behaviour or abusive language. Suspects must not be denied reasonable access to water, medication, or restrooms. Nor can they be unnecessarily humiliated in front of other shoppers; the investigation should be conducted in a private room if possible. Unless it is obvious, the people exercising the detention should immediately identify and explain themselves. ${ }^{99}$ Some American statutes set specific outer limits (for example, two hours or until the police arrive), but all prohibit detention beyond a reasonable time. And once an investigation uncovers facts that negate the

Johnson v K-Mart Enterprises, 297 NW (2d) 74 (Wis Ct App 1980). Special problems arise if a mistaken belief is the product of several minds. One employee sees a customer, who is wearing a bulky jacket, pick up an item; another employee sees the same individual leave the store without paying. Does the merchant have probable cause for intervention? If there was a gap — in terms of either time or sightlines - between the observation of the first employee and that of the second, then the facts may not support an inference of theft. After all, the customer may have originally intended to buy the item, only to decide otherwise and put it down during the gap: Wisner v SS Kresge Co, 465 SW (2d) 666 (Mo Ct App 1971).

Holguin v Sally Beauty Supply Inc, 264 P (3d) 732 (N Mex Ct App 2011).

Street $v$ Shoe Carnival Inc, $660 \mathrm{NE}$ (2d) 1054 (Ind Ct App 1996).

Causey v Katz \& Bestoff Inc, 539 So (2d) 994 (La Ct App 1989); cf Clark v IH Rubenstein Inc, 326 So (2d) 497 (La Sup Ct 1976).

Wilde v Schwegmann Bros Giant Supermarkets Inc, 160 So (2d) 839 (La Ct App 1964); Jefferson Stores Inc $v$ Caudell, 228 So (2d) 99 (Fla Dist Ct App 1969) [Jefferson].

Jefferson, ibid.

Lukas v JC Penney Co, 378 P (2d) 717 (Or Sup Ct 1963). 
original appearance of probable cause, detention is no longer justified. ${ }^{100}$ A failure to adhere to the reasonableness standard will place the statute out of the merchant's reach.

If the preceding requirements and restrictions are observed, the statutes shift the balance traditionally struck between personal liberty and private property. Despite the absence of any actual criminal behaviour, ${ }^{101}$ a shopkeeper can apprehend a suspected shoplifter without fear of legal repercussions. Some states expressly immunize the merchant against both civil claims and criminal prosecutions; others simply authorize acts that otherwise would be considered unlawful.

\section{ADDITIONAL ISSUES}

Every American state has shopkeeper's immunity legislation and all of those statutes share the same basic features. Looking forward to the final section of this article, this suggests that it would be a fairly simple matter to similarly protect Canadian merchants, even if, in the absence of legislative initiative, the task fell to the courts. That possibility takes on a very different light, however, as soon as the focus shifts from the general to the specific. Despite working within a common framework, the American statutes differ, sometimes dramatically, on details.

An exhaustive examination of those statutes is beyond the scope of this article. ${ }^{102}$ This section merely illustrates the range of issues that ought to be addressed in conjunction with the creation of a shopkeeper's immunity.

\section{a. Which Parties?}

Although the rule in Collyer ${ }^{103}$ was intended for use by any property owner, the American statutes focus more specifically on the problem of shoplifting. The paradigm involves a merchant who observes an individual in the apparent act of stealing merchandise. Occasionally, however, courts and legislatures take a broader view.

The merchant's privilege naturally encompasses not only merchants themselves, but also their employees and agents. Should protection also be available to security personnel who are employed not by the merchant, but rather by a security company that the merchant retained to provide services? ${ }^{104}$ What about security personnel employed by a shopping mall for the benefit of its tenants? More fundamentally, should immunity be restricted to shopkeepers or should it extend to other types of businesses that are similarly vulnerable to heightened risks of stolen property and legal liability? While most statutes are confined to

Latek v K Mart Corp, 401 NW (2d) 503 (Neb Sup Ct 1987).

Civil law requires proof on a balance of probabilities; criminal law requires proof beyond a reasonable doubt. Because of that difference, a court hearing a tort claim for false imprisonment may find that theft was proven even if the accused was acquitted in criminal proceedings. That is true in both America and Canada: Tota v Alexander's, 314 NYS (2d) 93 (Sup Ct 1968); Hayward, supra note 45 at para 69. Of course, if the civil court concludes that a theft did occur, the merchant was likely justified in detaining the plaintiff shoplifter.

Bishop v Bockoven Inc, $260 \mathrm{NW}$ (2d) 488 (Neb Sup Ct 1977) (a security guard held to fall outside of the statute). 
the paradigm, some states also grant immunity to libraries. ${ }^{105}$ Stretching the analogy even further, a few states provide protection for cinemas who suspect patrons of surreptitiously recording films ${ }^{106}$ and casinos who suspect gamblers of cheating. ${ }^{107}$ Florida's legislation, however, gave no relief to the owner of a greyhound racing track who detained two gamblers suspected of swindling a cashier. ${ }^{108}$

Turning to the other side of the story, the statutes typically apply to the apprehension of "shoplifters" - that is, ostensible customers who steal merchandise. Even within the context of self-service stores, however, suspicion may fall on other characters as well. Most statutes permit a merchant to hold an accomplice who, without personally purloining goods, is believed to be a decoy or a lookout for a suspected shoplifter. ${ }^{109}$ In contrast, a merchant never has authority to detain an officious bystander who, despite being uninvolved in the principal event, presumes to intervene on behalf of an accused thief. ${ }^{110}$ Finally, given the increasing incidence of inside theft, ${ }^{111}$ it may be appropriate to extend the merchant's privilege to the detention of employees who are thought to be involved in stealing stock. ${ }^{112}$

\section{b. Which Wrongs?}

Most of the American cases arise in the expected way - namely, a merchant is sued for false imprisonment after detaining a suspected shoplifter who was actually innocent of any theft. Other possibilities nevertheless arise on both sides of the relationship.

Statutes that narrowly refer to shoplifting create problems when merchants perceive other forms of wrongdoing. Instead of stealing merchandise, a shopper may be accused of damaging goods on a shelf. ${ }^{113}$ More commonly, an individual may be suspected of switching price tags, ${ }^{114}$ passing bad cheques or counterfeit currency, ${ }^{115}$ or fraudulently obtaining goods without payment. ${ }^{116}$ So too, while an employee who steals goods may fall within the definition of "shoplifting," that term does not easily apply if an employee is suspected of taking money from the till. ${ }^{117}$

Difficulties develop on the other side of the dispute if a statute narrowly enumerates the claims against which a merchant may be immunized. False imprisonment is merely the most obvious risk. Depending upon the circumstances, an innocent person who feels aggrieved by detention may sue for assault, battery, intimidation, defamation, malicious prosecution,

See e.g. Cal Penal Code $\S \S 490.5(f)(1)-(4)$, (7) (2010).

See e.g. Ga Code Ann $\S 51-7-62$ (Supp 2012).

See e.g. NRS $\S 171.1235$ (2010).

Washington County Kennel Club Inc v Edge, 216 So (2d) 512 (Fla Dist Ct App 1968).

There is no power to apprehend a person who is merely in the company of a shoplifter: Duran v Buttrey Food Inc, 616 P (2d) 327 (Mont Sup Ct 1980). It is a different story, however, if there is probable cause for believing that an individual is an accomplice: Williams $v$ Jitney Jungle Inc, 910 So (2d) 39 (Miss Ct App 2005).

State v Griffin, 376 NE (2d) 1364 (Ohio Akron Mun Ct 1977).

See Part II, above.

Dietz v Finlay Fine Jewelry Corp, 754 NE (2d) 958 (Ind Ct App 2001).

McNeely v National Tea Co, 653 So (2d) 1231 (La Ct App 1995).

State v Hauck, 209 NW (2d) 580 (Neb Sup Ct 1973).

Wolin v Abraham \& Straus, 316 NYS (2d) 377 (Sup Ct 1970); Taylor v Super Discount Market Inc, 441

SE (2d) 433 (Ga Ct App 1994).

De Angelis v Jamesway Dept Store, 501 A (2d) 561 (NJ Super Ct App Div 1985).

Chenkin v Times Square Stores Corp, 415 NYS (2d) 468 (Sup Ct App Div 1979). 
intentional infliction of mental distress, invasion of privacy, occupier's liability, or negligence. $^{118}$

\section{c. Other Restrictions}

Because there is no single right way to balance personal liberty and private property, the American statutes contain a variety of other control mechanisms. Some continue to justify detention as a way of directly protecting property. On that view, an immunity may be available only if a merchant has probable cause to believe that apprehension of an individual will also facilitate the immediate recovery of stolen goods. ${ }^{19}$ Such provisions provide no protection if a shopkeeper detains a person suspected of shoplifting on a previous occasion. ${ }^{120}$

Other statutes impose a geographical, rather than a temporal, restriction. The legislation commonly requires a merchant to apprehend a suspected shoplifter within the business premises. ${ }^{121}$ Sympathetic courts, however, may generously define that area to include adjoining sidewalks or common areas inside shopping malls. ${ }^{122}$ Authority may be extended much further in the event of fresh pursuit. ${ }^{123}$

\section{MANN V. CANADIAN TIRE CORP.}

Until very recently, the merchant's immunity was confined to American law. In 2016, however, it was introduced into Canadian law by Justice Akhtar in Mann v. Canadian Tire Corp. $^{124}$

The basic facts were not seriously contested. Steve Mann, a Professor of Electrical and Computing Engineering at the University of Toronto, visited a Canadian Tire store in Toronto. Having purchased several items, he headed for the exit, but triggered a theft detection alarm. When an employee came to investigate, Mann dropped his purchases and began filming the proceedings with his phone, explaining that he was collecting evidence "for his lawyer." 25 Flummoxed and frightened by the bizarre behaviour, the employee walked away. Mann followed her to the customer service desk, where several other employees joined the story. Mann continued filming and repeatedly asked if he was allowed to leave. He was told that he would have to wait until the store's manager dealt with the video. The episode seemingly came to an end after Mann deleted the filmed footage and the employees called the police. Upon exiting the store, however, Mann mistakenly believed that Canadian Tire employees were chasing him, panicked, and sprinted down the sidewalk. Harley Davidson Inc, 534 SE (2d) 656 (NC Ct App 2000).

See e.g. Fla Stat Ann $§ 812.015(3)$ (a) (2013). See Part IV.A.1.b.iii, above.

121 See e.g. Ariz Rev Stat Ann § 13-1805(c) (2010). 
While looking over his shoulder for the non-existent pursuers, he cracked his head on overhead pipes and collapsed unconscious to the ground. ${ }^{126}$

For the purposes of the litigation that followed, Mann supplemented those facts with several serious accusations. The employee who initially investigated the alarm, he claimed, uttered a threat: "[l]eave you die." 127 The situation at the customer service desk was purportedly even more menacing. Mann testified that an unidentified employee urged the others to "[r] ough him up," while a third worker issued an ultimatum: "[i]f you want to make it out alive - delete the video." 128

After viewing the store's surveillance video and considering the other evidence, Justice Akhtar dismissed Mann's allegations as the "fabrication" of a febrile imagination. ${ }^{129}$ That did not necessarily mean, however, that the defendant's conduct was non-tortious. There were two possibilities for false imprisonment. The first arose when Mann triggered the alarm as he initially approached the exit. That alarm, it appears, was false. Nothing in the judgment suggests an attempted theft. As soon as Mann began filming, however, the attending employee, upset and uncomfortable, made no effort to detain him. The second possibility occurred at the customer service desk. Having repeatedly asked if he was entitled to leave, Mann eventually was told "No, "cause the manager is going to come and have you delete that because you should not be recording." ${ }^{30}$ At that point, Mann was psychologically (though not physically) confined within the store. ${ }^{131}$ The circumstances, including the employees' words and actions, led him to believe that he was not at liberty to leave. As a result, Canadian Tire was liable unless it proved that its behaviour was justified.

The defendants argued for recognition of a shopkeeper's immunity. After canvassing the cases and commentaries, Justice Akhtar concluded that Canadian law knew no such defence, but he also believed that the doctrine's day had come. ${ }^{132}$ Law reform had been in the air for decades $^{133}$ and, in some respects at least, Parliament had demonstrated a desire to better protect shopkeepers. ${ }^{134}$ The traditional rules governing citizens' arrests reflect socioeconomic conditions that no longer exist. Self-service stores are convenient and efficient, but they also leave merchants vulnerable to theft. At the same time, video surveillance and electronic theft detection devices have substantially reduced the risk of unfounded accusations. Even as the incidence of shoplifting increases, ${ }^{135}$ shoppers are less likely to be detained without cause. Furthermore, although personal liberty, as enshrined in the Charter

126 The incident at Canadian Tire was not the first — or even the most dramatic - episode that Mann has experienced at a commercial establishment. See Avram Piltch, "Exclusive: Cyborg Steve Mann Details Alleged McDonald's Assault," Laptop (17 July 2012), online: <https://www.laptopmag.com/articles/ exclusive-cyborg-steve-mann-on-alleged-mcdonalds-assault $>$.

Mann, supra note 3 at para 7.

Ibid at para 10 .

Ibid at para 55.

Ibid at para 68 .

Bird, supra note 16 at 748; Higgins, supra note 21 at 242.

Carter v Canada (Attorney General), 2015 SCC 5 at para 44 (fundamentally changed circumstances justify judicial reform).

133 In 1986, the Law Reform Commission of Canada recommended an expansion of the private citizen's power of arrest. It urged Parliament to say that "anyone may arrest without warrant ... a person who he believes on reasonable grounds is committing or has just committed a criminal offence" (Report on Arrest (Ottawa: Law Reform Commission of Canada, 1986) at 25). 
of Rights and Freedoms, undoubtedly remains important, it does not invariably trump other interests. ${ }^{136}$ Given the extent to which modern governments intrude on private lives, it hardly needs to be said that "[c]ommon law man has lost the rougher edges of his individualism."137 Other intentional torts are vulnerable to mistake based defences, even when physical safety is at stake. ${ }^{138}$ And as the American model illustrates, a tightly circumscribed power of detention may significantly enhance the protection of property while causing relatively little loss of individual freedom.

Having decided to recognize a shopkeeper's privilege, Justice Akhtar adopted many of the limiting factors that are found in the American statutes:

1. There must be reasonable and probable grounds to believe that property is being stolen or has been stolen from the shopkeeper's place of business. A security alarm triggered when a person is in the process of leaving the store would be sufficient to provide such grounds.

2. The sole purpose of the detention must be to investigate whether any item is being stolen or has been stolen from the store.

3. The detention must be reasonable and involves inviting the suspect to participate in a search to resolve the issue. The privilege does not bestow a power upon the store owner to search the detainee without consent.

4. The period of detention should be as brief as possible and reasonable attempts to determine whether an item of property is being stolen or has been stolen should proceed expeditiously.

5. If the detained suspect refuses co-operation, the store owner is entitled to detain them using reasonable force whilst summoning the police and until they arrive. ${ }^{139}$

On the facts of Mann, "all but one of the conditions of the shopkeeper's privilege were met." 140 The false imprisonment was of "a minimal nature." "141 The episode lasted only thirteen minutes, the employees were respectful and non-threatening, the alarm provided probable cause to believe that goods may have been stolen, and initially at least, the employee intervened to investigate the possibility of theft. Once the parties moved to the customer service desk, however, the defendants detained Mann "for the purpose of

Cf Kovacs, supra note 48 at 596.

137 Peter Birks, An Introduction to the Law of Restitution, revised ed (Oxford: Clarendon Press, 1989) at 121.

138 For instance, liability for battery may be avoided through a plea of self-defence, which is available as long as the defendant acted in the reasonable - albeit mistaken - belief that the claimant was threatening harm: Gambriell v Caparelli (1974), 7 OR (2d) 205 at 209 (Co Ct). While acknowledging that a perceived threat of physical attack weighs more heavily than a perceived risk of stolen merchandise, Justice Akhtar said that since "the harm to a possible shoplifter is de minimis, the argument for the same type of defence [in favour of a shopkeeper] is overwhelming" (Mann, supra note 3 at para 42). Justice Akhtar did not mention the point, but his proposal is also supported by the Trespass to Property Act, supra note 49. Section 2 makes it an offence to enter or remain on premises without the occupier's consent. Section 9 authorizes an occupier to arrest a person believed, on reasonable and probable grounds, to be in violation of section 2. (In other provinces, the power of arrest is limited to peace officers or actual trespasses. See e.g. Trespass Act, RSBC 1996, c 462, s 10; Petty Trespass Act, RSA 2000, c P-11, s 4.) In appropriate circumstances, those provisions could be used against an individual who was both shoplifting and trespassing. A merchant's privilege would provide similar protection in connection with personal property. 
investigating the lawfulness of [his] actions and potentially deleting the video." 142 In that respect, the detention was unjustified and the confinement consequently tortious. ${ }^{143}$

\section{THE FUTURE OF THE SHOPKEEPER's PRIVILEGE IN CANADA}

It is too early to assess the impact of Justice Akhtar's formulation of a shopkeeper's privilege. Mann has yet to be judicially considered and, more surprisingly, the decision has not received academic comment. Given the practical significance of the issue, however, it is merely a matter of time before the question needs to be answered for Canadian law as a whole: should merchants be permitted to detain suspected shoplifters without fear of incurring liability for reasonable errors? If so, did Justice Akhtar properly formulate the governing test?

\section{A. The MANN TeST}

It is impossible to read Mann without being impressed. Justice Akhtar's analysis enjoys admirable breadth temporally — tracing the merchant's right of arrest from its common law origins; geographically - examining the laws of Canada, England, and the United States; and philosophically — carefully assessing the competing claims for personal liberty and private property. Inevitably, however, the resulting test leaves many questions unanswered. That understandably is true with respect to more esoteric issues - for example, is the privilege available to (1) libraries and cinemas as well as merchants, (2) merchants of services rather than goods, or (3) merchants who suspect employees of stealing cash? Silence on more pressing issues was less expected.

To begin, Justice Akhtar's test refers repeatedly to property that a shopkeeper believes "is being stolen or has been stolen" from its premises. ${ }^{144}$ Is the right of intervention subject to any time limit? The Lucky Moose $e^{145}$ provides a useful illustration. Anthony Bennett, it will be recalled, ${ }^{146}$ returned to the store, an hour after stealing a bike load of plants, to do some more shoplifting. Would David Chen be justified in detaining him? What if Bennett returned a day later? A week later? What if Bennett visited the store daily, but Chen chose not to detain him until he returned for the tenth time?

Ibid at para 73 .

Having imposed liability, the Court was required to assess damages. That task was predictably difficult. Although two years had passed since he had panicked and knocked himself unconscious, Mann claimed that he continued to be plagued by impaired concentration, headaches, insomnia, shoulder pain, back pain, indigestion, and stomach pain. Those losses, however, were too remote from the underlying tort. The question was whether it was reasonably foreseeable that a person of "reasonable fortitude and robustness" would sustain such injuries as a result of being briefly and courteously detained at a customer service desk: Mustapha v Culligan of Canada Ltd, 2008 SCC 27 at para 14. Suggesting that the plaintiff's injuries were actually a function of his "extremely sensitive personality traits," Justice Akhtar answered in the negative: Mann, ibid at para 80. In the end, although it was not clear that Mann had suffered any calculable loss, the parties were invited to provide written submissions on point. Mann, ibid at para 45

Supra note 78.

See Part III.A.1.b.iii, above. 
The third element in Justice Akhtar's test indicates that a suspected shoplifter must be invited to "participate in a search to resolve the issue." ${ }^{\prime 47}$ What is the nature and purpose of that search? Is it intended, notwithstanding the prohibition on non-consensual searches of the suspect, to determine whether the goods are available for recapture? Or is the exercise aimed at determining whether supposedly stolen goods have been hidden or misplaced somewhere within the premises? On the facts of The Lucky Moose, neither type of search would have made sense. As Chen correctly believed, Bennett had already stashed the stolen plants elsewhere.

Many American statutes contain a geographical limitation, typically by insisting that merchants exercise the right of detention on their business premises. In contrast, while the Mann test requires proof that the merchant suspected the detainee of stealing goods "from the shopkeeper's place of business," 148 it does not stipulate where the detention must occur. Would Chen now be entitled to invoke the privilege if he apprehended Bennett on the sidewalk outside The Lucky Moose? A block away in a different store? On a subway car? Alternatively, if Bennett returned to The Lucky Moose but fled after being approached, would Chen enjoy a right of fresh pursuit?

\section{B. Should A Privilege Exist?}

Ultimately, of course, the primary issue arising from Justice Akhtar's judgment is whether Canadian law should adopt a merchant's privilege in order to strike a better balance between the competing interests.

There is a danger of understating the case for personal liberty. Shoplifters obviously have little ground for complaint as long as they are not physically or psychologically abused. Sympathy may similarly be in short supply for those who effectively invite suspicion but are blessed with unusually forgiving juries. ${ }^{149}$ More significantly, Justice Akhtar carefully formulated the new doctrine with a view to protecting property rights while infringing individual freedoms as little as possible. And in practice, of course, innocent suspects can normally exonerate themselves easily enough — bags can be opened, receipts can be shown, pockets can be turned out, and so on. Many people prefer that path of least resistance. Personal liberty, however, generally entails the right to resist such intrusions, and unless it can be exercised obstinately and inconveniently, that right does not mean much. Imagine, for example, a routine visit to a store that ends with a demand - perhaps issued by a poorlytrained and non-uniformed teenage employee — to either remove your jacket for inspection or wait in a back room while an investigation is conducted. The employee may legitimately believe that probable cause exists, but you know that you have done nothing wrong. You may comply with the demand, viewing it as a small cost to be paid for the luxury of living in a just society, but you may equally regard it as an outrage, a step too far in the relentless erosion of individual freedoms. Should you, possibly one of few Canadians who has never shoplifted, ${ }^{150}$ have to put up with such treatment?

Mann, supra note 3 at para 45.

Ibid.

Based on the reported facts, some of the leading decisions are difficult to accept: Walters, supra note 38; Collyer, supra note 87.

See Part II, above. 
At the same time, there are reasons to believe that errors might be relatively infrequent. Suspicions no longer depend on the vagaries of human perception. There will always be a place for simple observation and interpretation, but electronic theft detection systems, while not infallible, often provide objective evidence. ${ }^{151}$ Furthermore, while a shopkeeper "has a financial motivation to thwart potential shoplifters," there is unlikely to be any "motivation to wrongfully detain a customer." 152 Innocent shoppers are apt to be put off by anything more than very general inquiries, so it stands to reason that merchants would generally refrain from abusing a shopkeeper's privilege. Casual employees may be less scrupulous about maintaining goodwill, but they also tend to be less concerned about shoplifting.

Ultimately, the decision to adopt or reject a shopkeeper's privilege is a function of philosophical and political considerations. Allowing merchants to detain suspected shoplifters would not, however, constitute a marked departure from the values of Canadian culture in the twenty-first century.

If the idea is accepted, should a shopkeeper's immunity be introduced judicially or legislatively? Opinion is likely to be divided. As demonstrated by Mann ${ }^{153}$ the judicial route is attractive insofar as it merely requires one interested party and an amenable judge. At the same time, given their obvious lack of interest in the matter, it presumably would require considerable effort to induce action from one legislative body, let alone all of the provinces and territories. So too, a common law rule would be capable of flexibly responding to novel situations and evolving needs. And a favourable decision by the Supreme Court of Canada could effectively secure a level of consistency that is unlikely to be achieved legislatively.

Other considerations point to a legislative approach. Because it allows one private citizen to infringe on the personal liberty of another, a merchant's privilege might benefit from the legitimacy that the legislative process confers. The rules could be formulated on the basis of objective studies rather than the pleadings of self-interested parties. And perhaps most significantly, legislators could comprehensively address the sorts of issues that have emerged from the American experience - for example, which parties and which wrongs? ${ }^{154}$

\section{CONCLUSION}

The underlying values are timeless. Personal liberty and the protection of property are natural incidents of human society. The surrounding circumstances, however, have changed dramatically since common law courts first formulated the rules governing private arrests and detentions. The currently prevailing model of retail business constitutes - for a disturbing number of people - an open invitation to theft. Canadian businesses lose billions of dollars a year to shoplifting. The cost of theft-prevention measures increases the burden further. And still, merchants too often hesitate to detain suspected thieves because the law provides so

Of course, merchants may not use such systems for a variety of reasons. A recent study revealed that only 48 percent of participating shopkeepers used merchandise alarms at least occasionally. Video surveillance ( 94 percent), "mystery shoppers" (64 percent), and observation mirrors (59 percent) are employed far more frequently: RCC, Securing the Bottom Line, supra note 8 at 13. 
little room for error. In the contest between shopkeepers and shoplifters, the rules, written to protect innocent third parties, practically favour the wrongdoers.

Mann $^{155}$ is a tremendously important case. Justice Akhtar momentously brought a merchant's privilege into Canadian law for the first time. The decision's fate ultimately will turn on the essentially political question as to how far other judges and legislators are prepared to go in allowing shopkeepers to act on well-founded suspicions. There are no easy answers. 
[this page is intentionally blank] 